Annals of Plant and Soil Research 22(4): 442-448 (2020)

https://doi.org/10.47815/apsr.2020.10019

\title{
Effect of lead on growth of warm season turf grasses
}

\author{
SYEDA AMENA KAUSAR ${ }^{1 *}$ AND K. SHAILAJA ${ }^{2}$ \\ ${ }^{1}$ Department of Environmental Science, University College for Science, Osmania University, Hyderabad, \\ Telangana 500009
}

Received: July, 2020; Revised accepted: September, 2020

\begin{abstract}
The ability to tolerate metals targeted for remediation in existing soil conditions is one of the important features possessed by plants used in phytoextraction programs. Pot experiments were conducted using Stenotaphrum dimidiatum (L.) Brongn, Zoysia matrella var. pacifica Goudsw and Axonopus compressus (Sw.) $P$. Beauv plants to identify ability of these turf grasses to withstand and tolerate lead when grown in contaminated soil from across Musi River region of Hyderabad which had lead metal in concentrations higher than permissible limits. Plants were exposed to 131.2, 223.3 and $326.2 \mathrm{mg} \mathrm{kg}^{-1}$ of lead in contaminated soil and examined under three metal exposure periods of 120, 240, and 360 days. Control samples were obtained by growing plants in normal soil with $42.2 \mathrm{mg} \mathrm{kg}^{-1}$ of lead. The pot cultures were maintained at a nursery under normal day light conditions and shoots were harvested every 60 days during the 360 days of study period from June 2017 to June 2018. Results showed that for all three grasses a decrease in heights was seen with an increase in soil lead concentrations and exposure time. Decrease in lengths was more for roots than shoots.Zoysia matrella was the most lead affected plant with a mean phytotoxicity of $14.7 \%$ compared to 10.9 and $8.5 \%$ seen in Stenotaphrum dimidiatum and Axonopus compressus. Lead tolerance was highest for Axonopus compressus with Metal tolerance index (MTI) of $91.5 \%$, followed by Stenotaphrum dimidiatum $(89.1 \%)$ and least by Zoysia matrella (85.3\%). At the highest given soil lead concentration of $326.2 \mathrm{mg} \mathrm{kg}^{-1}$ with Axonopus compressus was found significantly better having higher tolerance index compared to Zoysia matrella. The study concludes that Axonopus compressus popularly known as Carpetgrass has a greater scope for use in lead phytoextraction programs compared to the other two tested grasses as it had the ability to tolerate and withstand lead in contaminated soil at higher concentration.
\end{abstract}

Keywords: Phytoextraction, turf grasses, metal tolerance index, percent phytotoxicity

\section{INTRODUCTION}

Phytoremediation is an eco-friendly and economic solution to deal with the management of heavy metal contaminated sites. Heavy metal lead is considered as one of the obnoxious priority pollutants especially due to its nonbiodegradable nature making it persistent in soil. Both natural processes such soil erosion, leaching, decomposition, and volatilization and anthropogenic causes such as industrial discharges, leaded gasoline and paints, chemization of soil, sewage sludge soil applications, waste water irrigation, animal manures, transportation and waste incineration have elevated lead $(\mathrm{Pb})$ levels in surface soil. Remediation by using phytoextraction is the most sought and suggested method for large areas of land contaminated with low to moderate levels of metal pollution at shallow depths. Similar sites across Hyderabad (Telangana) in India had minimum $100-300 \mathrm{mg} \mathrm{Pb} \mathrm{kg}^{-1}$ of soil which was three times the permissible lead in irrigation soil (Chary et al, 2008). As these sites are close to human habitation and are mostly used as agricultural land, phytoextraction of lead at such sites is needed for risk mitigation. The ability to withstand and tolerate the higher concentrations of metals to be remediated by plants is an important characteristic feature to be utilized for remediation programs. Stenotaphrum dimidiatum (L.) Brongn, Zoysia matrella var. pacifica Goudsw and Axonopus compressus (Sw.) P. Beauv popularly known as Pembagrass, Zoysiagrass, and Carpetgrass respectively are the three plants considered in the present study as they are some of the native plants with assumed benefits of regional adaptability and availability. These plants are used for lawn, garden and road medians development by Hyderabad Municipal Development Authority (H.M.D.A), a government body take looks into infrastructure development works in and around the city of Hyderabad. These are some of the popular warm season grasses which arevery popular globally in 
tropical, subtropical, arid and semiarid climates as plants for covering large areas and fields of sports and public venues due to their fast spreading characteristics, multiple stress resistance such as water deficit and heat tolerance. Testing the ability of these plants to withstand and tolerate the lead when grown in contaminated soil will help us to generate information for their applicability in phytoextraction programmes in areas and locations that are metal enriched or are prone to such an exposure. Hence, the study was initiated using these turf grasses. Results from this study are intended to help the infrastructure development bodies such as Musi River Front Development Corporation Limited, Telangana to make informed decisions when selecting turfgrass cultivars for beautification of recreational sites across Musi River region which are lead contaminated.

\section{MATERIALS AND METHODS}

Soil preparation and analysis: Contaminated soil $(0-20 \mathrm{~cm})$ was collected from site location S2 across Musi River in Hyderabad (Kausar and Shailaja, 2018). Control samples $(0-20 \mathrm{~cm})$ were collected from an agricultural field. Both soils were added with $20 \%$ cattle dung based manure. The contaminated soil was further spiked using lead nitrate $\left[\mathrm{Pb}\left(\mathrm{NO}_{3}\right)_{2}\right]$ creating a concentration gradient of another 100 and $200 \mathrm{mg} \mathrm{Pb} \mathrm{kg}^{-1}$ to existing lead content. Treatments were normal soil, contaminated soil, contaminated soil +100 $\mathrm{mg} \mathrm{Pb} \mathrm{kg}^{-1}$, and contaminated soil $+200 \mathrm{mg} \mathrm{Pb}$ $\mathrm{kg}^{-1}$ which were notated as soil type $A, B, C$ and $D$ in present study. Total lead content in these soils was estimated by using Atomic Absorption Spectrophotometer as 42.2, 131.2, 223.3 and $326.2 \mathrm{mg} \mathrm{kg}^{-1}$ respectively which was then employed for pot cultures. Amount of lead in normal soil ranged between the natural background values (35-94 $\mathrm{mg} \mathrm{kg}^{-1}$ ) for soil in Hyderabad (Parth et al, 2011). The chemical

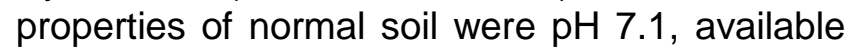
nitrogen, phosphorous and potassium 438, 23 and $202 \mathrm{~kg} \mathrm{ha}{ }^{-1}$ respectively, electrical conductivity $0.30 \mathrm{dSm}^{-1}$ and organic carbon $90 \mathrm{~g}$ $\mathrm{kg}^{-1}$. The contaminated soil had a $\mathrm{pH}$ 7.6, available nitrogen, phosphorous and potassium 394,23 and $196 \mathrm{~kg} \mathrm{ha}^{-1}$ respectively, electrical conductivity $0.95 \mathrm{dSm}^{-1}$ and organic carbon 120 $\mathrm{g} \mathrm{kg}^{-1}$.

Experimental design: Pot culture was done in 3 $\times 4 \times 3$ pattern, designated as $P \times Q \times R$, where $\mathrm{P}=$ number of plant types $=3$ (Stenotaphrum dimidiatum (L) Brongn, Zoysia matrella var. pacifica Goudsw and Axonopus compressus (Sw.) P. Beauv notated as P1, P2 and $P 3$ respectively, $Q=$ number of lead metal concentrations in soil including normal soil $=4(A$, $B, C \& D)$ and $R=$ number of replicates $=3$. Plant material was procured from H.M.D.A, Hyderabad and uniform sized stolons $(3 \mathrm{~cm}$ shoot and $2 \mathrm{~cm}$ root) were planted with six stolons per pot filled with $5 \mathrm{~kg}$ of test soils. The pots were centrally placed in the nursery located at Sanjeeviah Park, which had a plastic sheet on top side to prevent direct rain. A completely randomized design was maintained which was altered every week. Plants were grown for a period of 360 days between June 2017 and June 2018 and shoots were harvested every 60 days. Drought stress was avoided by keeping the soil moist throughout the study and watering using deionized water. The shoot length was measured before each cut by using geometrical scale and results were grouped under three metal exposure periods as I- 120 days (Mid of June- Mid of October), II- 240 days (Mid of October- Mid of February) and III- 360 days (Mid of February- Mid of June) corresponding to ongoing seasonal variations. The monthly temperature data (both minimum and maximum) for nursery site $17^{\circ} 26^{\prime} 01.1^{\prime \prime} \mathrm{N} 78^{\circ} 28^{\prime} 27.1^{\prime \prime} E$ was obtained from Climate Research Unit, University of East Anglia using global level gridded data for $0.5^{\circ *} 0.5^{\circ}$ degrees ( Harris et al, 2020). Physical sign of stress was monitored on daily basis based on guidelines of McCauley et al (2009). Percent Phytotoxicity (Ray and Banerjee, 1981) and Metal Tolerance index (Iqbal and Rahmati, 1992) were calculated to evaluate effect of lead on plant growth. Analysis of variance (ANOVA) with two factors (plant type and lead concentrations) along with multiple comparisons using Bonferroni post-test was done and $p<0.05$ was considered as statistically significant. Data were prepared and analyzed by Microsoft excel and Graph pad prism 7.0 software. 


\section{RESULTS AND DISCUSSION}

\section{Effect of lead at varied concentrations}

During the entire study period $100 \%$ survival and no visual signs of phytotoxicity such as chlorosis, wilting, necrosis in any treatment were seen for all three grasses. However, a morphological variation in the form of decrease in plants height was seen with increasing lead concentration levels and lead exposure periods. A greater decrease in root growth was seen. This is because roots slowly get physically blocked by the lead ions thereby limiting nutrient uptake and water transport gets affected reducing growth of roots and then plant as a whole (Sharma and Dubey, 2005). The decrease in root length was limited upto $18 \%$ in Stenotaphrum dimidiatum, $29.5 \%$ in Zoysia matrella and $14.2 \%$ in Axonopus compressus as compared to respective controls (Fig.1). Maximum decrease in shoot lengths at the highest given lead concentration of $326.2 \mathrm{mg} \mathrm{Pb}$ $\mathrm{kg}^{-1}$ was $12.9 \%$ in Stenotaphrum dimidiatum, $14.7 \%$ in Zoysia matrella and $11.7 \%$ in Axonopus compressus. For grasses as the plant height or stem length is the sum of the lengths of each of the internodes, the decrease in shoot length observed was directly related to internode spacings which was also reduced by $8.1,9$ and $6.6 \%$ for P1, P2 and P3 plants respectively.

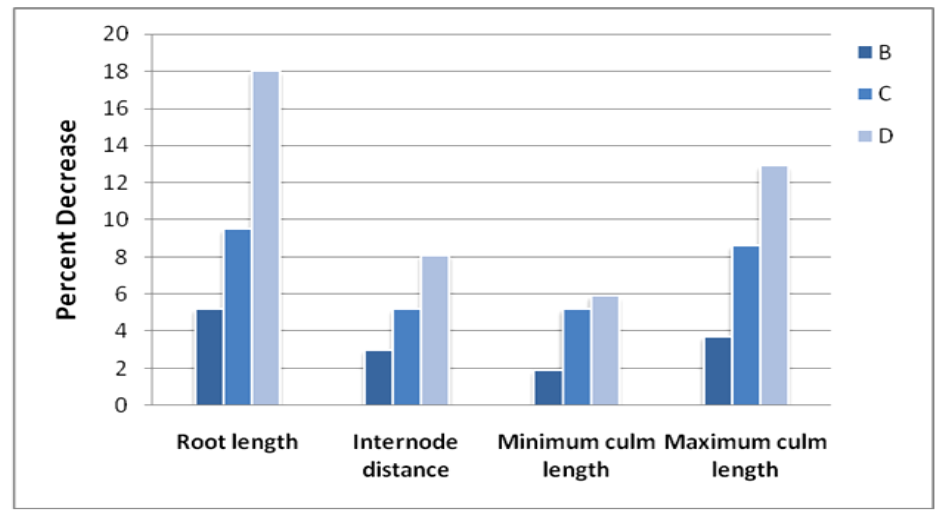

Stenotaphrum dimidiatum (L) Brongn

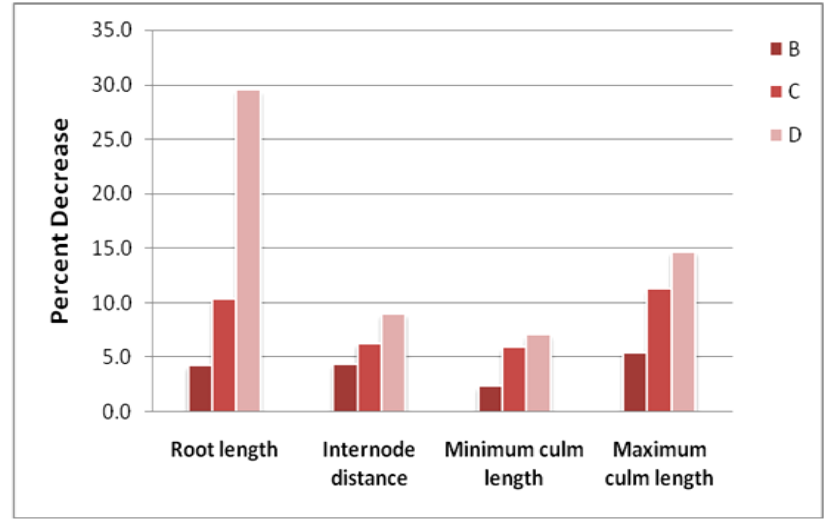

Zoysia matrella var. pacifica Goudsw

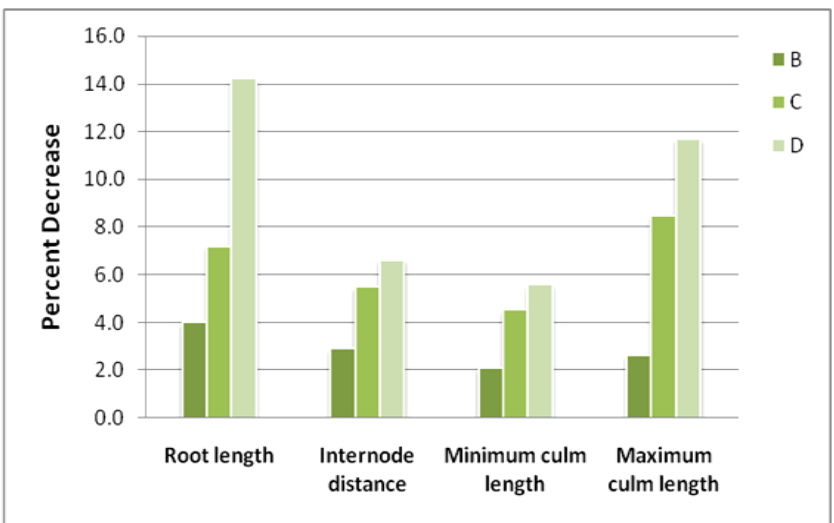

Axonopus compressus (Sw.) P. Beauv

Fig. 1:Effect of lead on test plants in contaminated soil

\section{Effect of day temperatures}

Internode distances and culm lengths in both normal and contaminated soils had a temperature dependent curvilinear growth pattern seen for all the four treatments where longer lengths were recorded when day temperature was optimum $\left(27\right.$ to $\left.35^{\circ} \mathrm{C}\right)$ for growth of warm season grasses and least lengths were seenwhentemperatures wereeither cool or hot for these plants to grow. Shoot lengths in exposure period I where $T_{\min }$ and $T_{\max }$ 
ranged between $21.8^{\circ} \mathrm{C}$ and $34.7^{\circ} \mathrm{C}$ were longest compared to the least lengths recorded for exposure period II at cooler temperatures (16.3 and $32.8^{\circ} \mathrm{C}$ ) indicating not very favourable temperatures for growth of warm season grasses. In this study it was observed that Stenotaphrum dimidiatum (P1 plant) exhibited a lesser degree of decrease during exposure period II compared to the other two tested plants Zoysia matrella and Axonopus compressus which is mostly due to the characteristic nature of genus Stenotaphrum to be better tolerant to colder and frosting temperatures compared to several known warm season grasses (MillaLewis et al, 2013).

Table 1: Shoot length $(\mathrm{cm})$ at different soil lead concentrations and exposure periods; and turf grasses

\begin{tabular}{|c|c|c|c|c|c|c|c|c|c|c|}
\hline \multirow[b]{2}{*}{ Plant } & \multirow[b]{2}{*}{ Soil } & \multicolumn{3}{|c|}{ Exposure period I } & \multicolumn{3}{|c|}{ Exposure period II } & \multicolumn{3}{|c|}{ Exposure period III } \\
\hline & & $\begin{array}{c}\text { Internode } \\
\text { distance }\end{array}$ & \begin{tabular}{|c|} 
Minimum \\
Culm \\
length
\end{tabular} & $\begin{array}{c}\text { Maximum } \\
\text { Culm } \\
\text { length }\end{array}$ & $\begin{array}{l}\text { Internode } \\
\text { distance }\end{array}$ & \begin{tabular}{|c|} 
Minimum \\
Culm \\
length
\end{tabular} & $\begin{array}{c}\text { Maximum } \\
\text { Culm } \\
\text { length }\end{array}$ & $\begin{array}{l}\text { Internode } \\
\text { distance }\end{array}$ & \begin{tabular}{|c|} 
Minimum \\
Culm \\
length
\end{tabular} & $\begin{array}{l}\text { Maximum } \\
\text { Culm } \\
\text { length }\end{array}$ \\
\hline \multirow{4}{*}{ P1 } & $A$ & $\begin{array}{c}4.70 \pm \\
0.25\end{array}$ & $\begin{array}{c}5.30 \pm \\
0.41\end{array}$ & $\begin{array}{c}18.73 \pm \\
0.92\end{array}$ & $\begin{array}{c}4.13 \pm \\
0.46\end{array}$ & $\begin{array}{c}4.62 \pm \\
0.43\end{array}$ & $\begin{array}{c}15.75 \pm \\
1.87\end{array}$ & $\begin{array}{c}4.62 \pm \\
0.29\end{array}$ & $\begin{array}{c}5.30 \pm \\
0.45\end{array}$ & $\begin{array}{c}18.00 \pm \\
1.04\end{array}$ \\
\hline & $\mathrm{B}$ & $\begin{array}{c}4.63 \pm \\
0.26\end{array}$ & $\begin{array}{c}5.23 \pm \\
0.12\end{array}$ & $\begin{array}{c}18.30 \pm \\
1.54\end{array}$ & $\begin{array}{c}3.93 \pm \\
0.38\end{array}$ & $\begin{array}{c}4.50 \pm \\
0.36\end{array}$ & $\begin{array}{c}15.00 \pm \\
2.0\end{array}$ & $\begin{array}{c}4.50 \pm \\
0.21\end{array}$ & $\begin{array}{c}5.20 \pm \\
0.17\end{array}$ & $\begin{array}{c}17.25 \pm \\
2.44\end{array}$ \\
\hline & C & $\begin{array}{c}4.58 \pm \\
0.29\end{array}$ & $\begin{array}{c}5.13 \pm \\
0.49\end{array}$ & $\begin{array}{c}18.00 \pm \\
2.06\end{array}$ & $\begin{array}{c}3.85 \pm \\
0.40\end{array}$ & $\begin{array}{c}4.30 \pm \\
0.52\end{array}$ & $\begin{array}{c}13.87 \pm \\
1.69\end{array}$ & $\begin{array}{c}4.33 \pm \\
0.38\end{array}$ & $\begin{array}{c}5.00 \pm \\
0.65\end{array}$ & $\begin{array}{c}16.20 \pm \\
2.72\end{array}$ \\
\hline & $\mathrm{D}$ & $\begin{array}{c}4.40 \pm \\
0.26\end{array}$ & $\begin{array}{c}5.02 \pm \\
0.49\end{array}$ & $\begin{array}{c}17.80 \pm \\
0.90\end{array}$ & $\begin{array}{c}3.70 \pm \\
0.39\end{array}$ & $\begin{array}{c}4.25 \pm \\
0.26\end{array}$ & $\begin{array}{c}12.85 \pm \\
2.34\end{array}$ & $\begin{array}{c}4.20 \pm \\
0.58\end{array}$ & $\begin{array}{c}4.70 \pm \\
0.66\end{array}$ & $\begin{array}{c}15.27 \pm \\
3.3\end{array}$ \\
\hline \multirow{4}{*}{ P2 } & A & $\begin{array}{c}2.53 \pm \\
0.10\end{array}$ & $\begin{array}{c}6.57 \pm \\
0.21\end{array}$ & $\begin{array}{c}17.73 \pm \\
1.18\end{array}$ & $\begin{array}{c}2.12 \pm \\
0.25\end{array}$ & $\begin{array}{c}4.50 \pm \\
0.34\end{array}$ & $\begin{array}{c}14.93 \pm \\
1.24\end{array}$ & $\begin{array}{c}2.37 \pm \\
0.33\end{array}$ & $\begin{array}{c}5.80 \pm \\
0.47\end{array}$ & $\begin{array}{c}17.05 \pm \\
0.92\end{array}$ \\
\hline & B & $\begin{array}{c}2.47 \pm \\
0.08\end{array}$ & $\begin{array}{c}6.50 \pm \\
0.30\end{array}$ & $\begin{array}{c}17.20 \pm \\
1.12\end{array}$ & $\begin{array}{c}1.98 \pm \\
0.12\end{array}$ & $\begin{array}{c}4.33 \pm \\
0.32\end{array}$ & $\begin{array}{c}13.77 \pm \\
1.51\end{array}$ & $\begin{array}{c}2.27 \pm \\
0.24\end{array}$ & $\begin{array}{c}5.67 \pm \\
0.32\end{array}$ & $\begin{array}{c}16.10 \pm \\
1.10\end{array}$ \\
\hline & C & $\begin{array}{c}2.45 \pm \\
0.08\end{array}$ & $\begin{array}{c}6.33 \pm \\
0.40\end{array}$ & $\begin{array}{c}16.83 \pm \\
1.11\end{array}$ & $\begin{array}{c}1.97 \pm \\
0.10\end{array}$ & $\begin{array}{c}4.17 \pm \\
0.33\end{array}$ & $\begin{array}{c}12.38 \pm \\
1.37\end{array}$ & $\begin{array}{c}2.17 \pm \\
0.23\end{array}$ & $\begin{array}{c}5.40 \pm \\
0.28\end{array}$ & $\begin{array}{c}15.07 \pm \\
1.28\end{array}$ \\
\hline & $\mathrm{D}$ & $\begin{array}{c}2.42 \pm \\
0.15\end{array}$ & $\begin{array}{c}6.28 \pm \\
0.47\end{array}$ & $\begin{array}{c}16.60 \pm \\
0.91\end{array}$ & $\begin{array}{c}1.87 \pm \\
0.16\end{array}$ & $\begin{array}{c}4.10 \pm \\
0.28\end{array}$ & $\begin{array}{c}11.83 \pm \\
1.29\end{array}$ & $\begin{array}{c}2.12 \pm \\
0.19\end{array}$ & $\begin{array}{c}5.33 \pm \\
0.57\end{array}$ & $\begin{array}{c}14.17 \pm \\
1.86\end{array}$ \\
\hline \multirow{4}{*}{ P3 } & A & $\begin{array}{c}4.03 \pm \\
0.18\end{array}$ & $\begin{array}{c}12.67 \pm \\
0.99\end{array}$ & $\begin{array}{c}22.13 \pm \\
2.45\end{array}$ & $\begin{array}{c}3.63 \pm \\
0.27\end{array}$ & $\begin{array}{c}11.13 \pm \\
0.76\end{array}$ & $\begin{array}{c}15.67 \pm \\
1.63\end{array}$ & $\begin{array}{c}3.93 \pm \\
0.58\end{array}$ & $\begin{array}{c}11.50 \pm \\
1.09\end{array}$ & $\begin{array}{c}21.67 \pm \\
2.25\end{array}$ \\
\hline & B & $\begin{array}{c}3.97 \pm \\
0.36\end{array}$ & $\begin{array}{c}12.47 \pm \\
1.28\end{array}$ & $\begin{array}{c}21.77 \pm \\
2.45\end{array}$ & $\begin{array}{c}3.50 \pm \\
0.43\end{array}$ & $\begin{array}{c}10.80 \pm \\
0.84\end{array}$ & $\begin{array}{c}15.17 \pm \\
1.91\end{array}$ & $\begin{array}{c}3.80 \pm \\
0.52\end{array}$ & $\begin{array}{c}11.30 \pm \\
1.12\end{array}$ & $\begin{array}{c}21.00 \pm \\
1.12\end{array}$ \\
\hline & $\mathrm{C}$ & $\begin{array}{c}3.90 \pm \\
0.34\end{array}$ & $\begin{array}{c}12.33 \pm \\
1.24\end{array}$ & $\begin{array}{c}21.33 \pm \\
1.99\end{array}$ & $\begin{array}{c}3.43 \pm \\
0.23\end{array}$ & $\begin{array}{c}10.33 \pm \\
1.63\end{array}$ & $\begin{array}{c}13.53 \pm \\
2.16\end{array}$ & $\begin{array}{c}3.63 \pm \\
0.27\end{array}$ & $\begin{array}{c}11.07 \pm \\
0.94\end{array}$ & $\begin{array}{c}19.88 \pm \\
2.31\end{array}$ \\
\hline & $\mathrm{D}$ & $\begin{array}{c}3.87 \pm \\
0.27\end{array}$ & $\begin{array}{c}12.30 \pm \\
1.28\end{array}$ & $\begin{array}{c}21.13 \pm \\
1.85\end{array}$ & $\begin{array}{c}3.40 \pm \\
0.20\end{array}$ & $\begin{array}{c}10.23 \pm \\
1.15\end{array}$ & $\begin{array}{c}12.73 \pm \\
1.09\end{array}$ & $\begin{array}{c}3.57 \pm \\
0.41\end{array}$ & $\begin{array}{c}10.83 \pm \\
1.06\end{array}$ & $\begin{array}{c}19.10 \pm \\
1.29\end{array}$ \\
\hline
\end{tabular}

\section{Effect of metal exposure periods}

The internode spacing and culm lengths were affectedby duration to which a plant was exposed to lead. All three test plants performance had effective shoot growth within optimal temperature ranges. However, plants in both normal soil at low lead level and in contaminated soil with varied lead concentrations during exposure period III did not exhibit an effective growth in shoot despite of having a favourable day temperature (19 and $39.4^{\circ} \mathrm{C}$ ) for growth of warm season grasses indicating the long term effect of lead exposure on plants height in the form of reduced growth of plants (Table 1). Such an inhibitory effect of lead at both low concentration and prolonged exposure periods have been reported for Triticum aestivum, Oryza sativa L., Brachiaria mutica, Brachiaria decumbens, Brachiaria brizantha and Panicum maximum (Kaur et al. 2012; Khan et al 2018; Nascimento et al 2014).

\section{Impact of lead on tolerance indices}

Phytotoxicity was seen to increase with an increase in soil lead concentrations for all three plants. In contaminated soil Zoysia 
matrella(P2) experienced highest lead induced toxicity followed by Stenotaphrum dimidiatum (P1) and least effect was seen in Axonopus compressus (P3). The phytotoxicity values at highest soil lead concentration D was $18.1 \%$ in P1 plant, $29.5 \%$ in P2 plant, and $14.2 \%$ in P3 plant. Metal tolerance index (MTI) had an inverse relation to soil $\mathrm{Pb}$ concentration levels where the increase in soil $\mathrm{Pb}$ levels decreased the plants tolerance towards this metal. The mean MTI following order of hierarchy: P3 $(91.5 \%)>$ P1 $(89.1 \%)>P 2 \quad(85.3 \%)$. In the presence of lead the plant growth tolerance indices were negatively affected in Pisum sativum, Zea mays, Paspalum distichum and Cynodon dactylon (Nas and Ali, 2018).

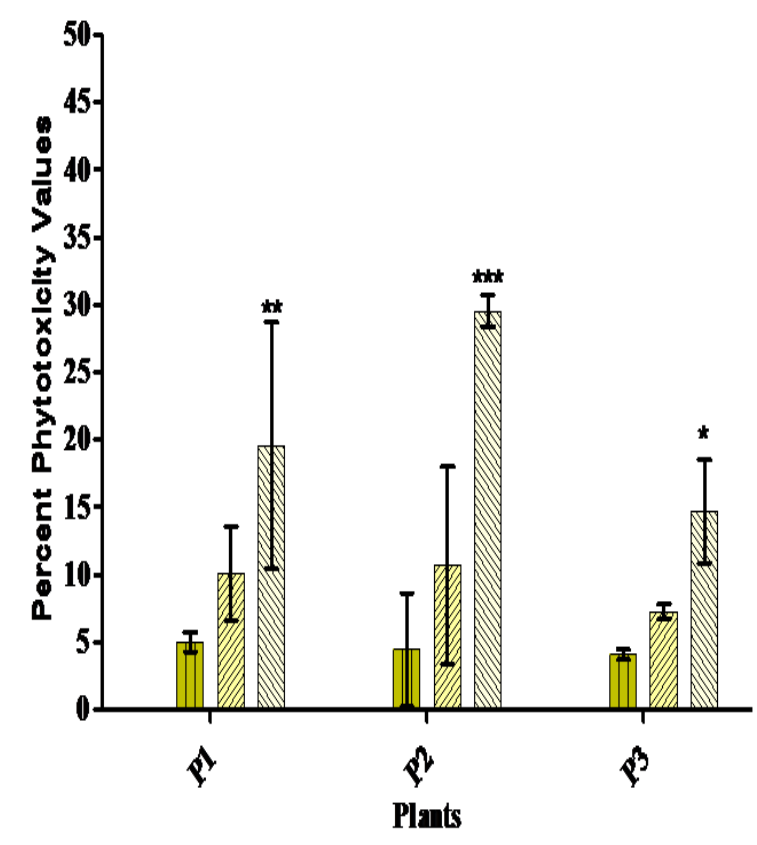

(a) Percent Phytotoxicity

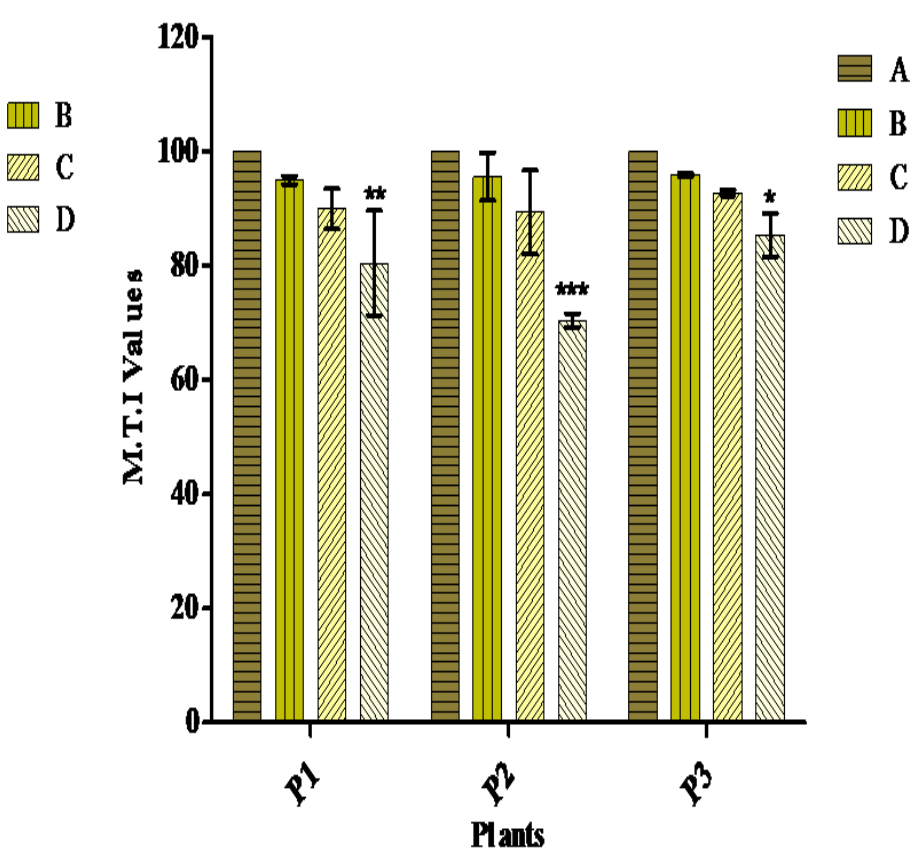

(b) Metal Tolerance Index

Fig. 2: Tolerance indices (Mean \pm S.E.M) compared to the respective controls; where P1 is Stenotaphrum dimidiatum, P2 is Zoysia matrella and P3 is Axonopus compressus

\section{Results of statistical test}

Comparing growth indices in contaminated and control soil for each plant indicated a significant difference between control and contaminated samples at the highest soil $\mathrm{Pb}$ concentration (326.2 $\mathrm{mg} \mathrm{Pb} \mathrm{kg}^{-1}$ ) while all comparisons were not significant. The difference was found significant for Z.matrella $(p<0.001)$ followed by $S$. dimidiatum $(p<0.01)$ and then $A$. compressus $(p<0.05)$ indicating greater effect of lead on Zoysia grass (Fig.2). Phytotoxicity percent and metal tolerance indices when further compared between the grasses a significant variation was observed due to variation in soil lead levels $(p<0.0065)$. Bonferroni posttest revealed lead at a concentration of $326.2 \mathrm{mg} \mathrm{Pb}$ $\mathrm{kg}^{-1}$ created a significant difference $(\mathrm{p}<$ 0.05)between Zoysia matrella and Axonopus compressus plants while all other comparisons made between plants at all treatments did not show a significant difference (Fig. 3). Our findings are in line with previous findings by Ukoh et al (2019) who indicated usefulness of Axonopus compressus in remediating lead metal from contaminated soil and by Tow et al (2018) who highlighted high metal tolerance without plant mortality exhibited by this plant when grown in $600 \mathrm{mg} \mathrm{Mo} \mathrm{kg}{ }^{-1}$ in molybdenum contaminated soil. All the three plants, therefore, experienced a low level of lead induced toxicity ranging between 8.5 and $10.9 \%$ and were found adaptable to the prevailing soil conditions with a high lead tolerance which ranged between 85.3 and 91.5 per cent. 


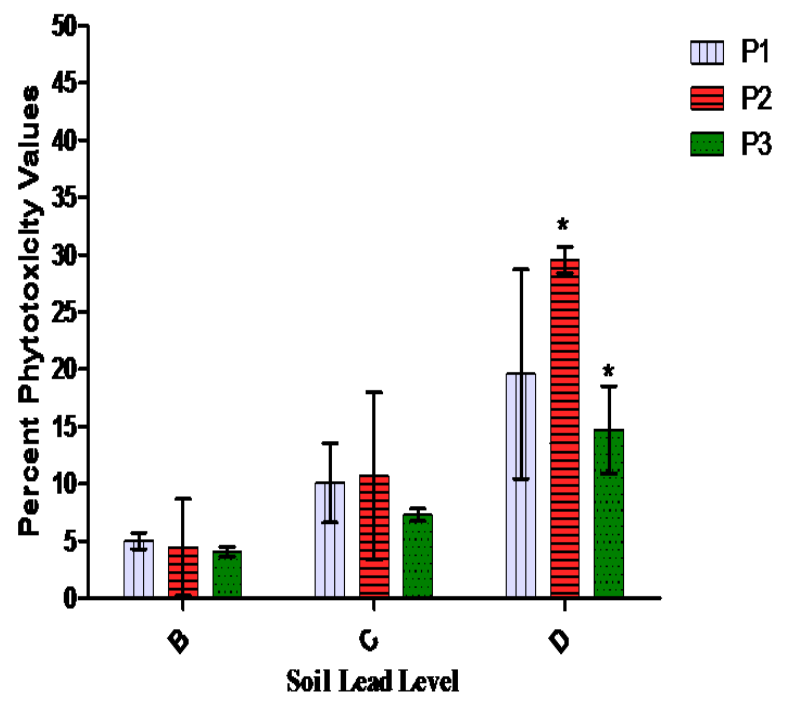

(a) Percent Phytotoxicity

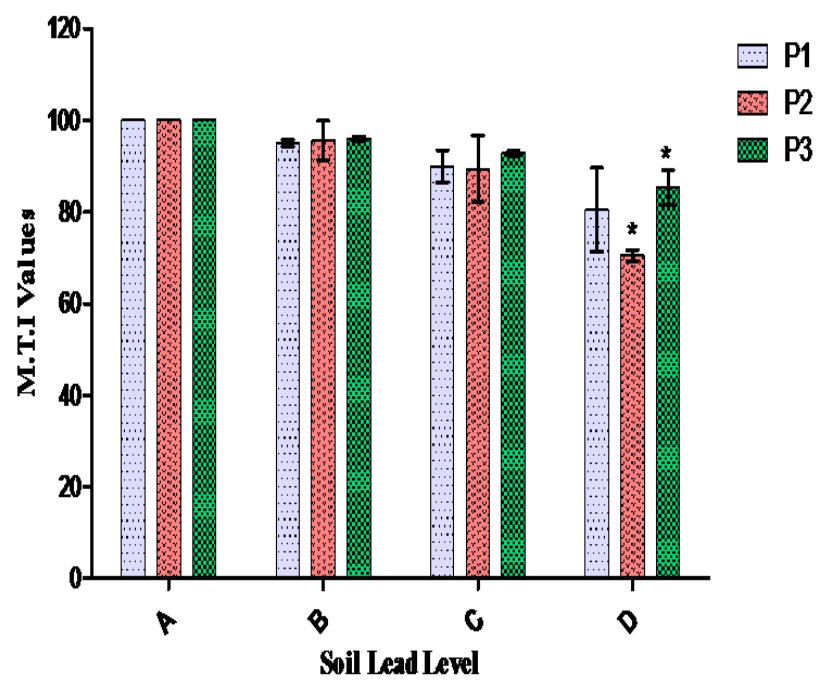

(b) Metal Tolerance Index

Fig. 3: Tolerance indices compared among the plants at a given soil lead concentration

From these results it can be concluded that the tested grasses Stenotaphrum dimidiatum (L.) Brongn, Zoysia matrella var. pacifica Goudsw and Axonopus compressus (Sw.) P. Beauv have the tenacity to be a plant suitable in lead phytoremediation in soil having lead concentrations between 42.2 and $326.2 \mathrm{mg} \mathrm{kg}^{-1}$. The study further indicated that Axonopus compressus (Sw.) P. Beauv was one of the tested turf plants, Zoysia matrella to be

\section{ACKNOWLEDGEMENTS}

We thank Dr. J. Swamy (Botanical survey of India, Deccan regional centre) and Dr. K. Sri

\section{REFERENCES}

Chary, N. S., Kamala, C. T., and Raj, D. S. (2008) Assessing risk of heavy metals from consuming food grown on sewage irrigated soils and food chain transfer. Ecotoxicology and environmental safety 69(3): 513-524.

Harris, I., Osborn, T. J., Jones, P., and Lister, D. (2020) Version 4 of the CRU TS monthly high-resolution gridded multivariate climate dataset Scientific data 7(1): 1-18.

lqbal, M. Z., and Rahmati, K. (1992) Tolerance of Albizia lebbeck to $\mathrm{Cu}$ and $\mathrm{Fe}$ application Ekologia, (CSFR) 11(4): 427430. a more suitable choice for remediation and adding aesthetic value in soils having high initial soil lead levels of $326.2 \mathrm{mg} \mathrm{Pb} \mathrm{kg}^{-1}$ due to their significant difference in tolerance and toxicity indices compared to this plant. However as present studies are under ideal temperature and moisture conditions with no disease or insect pressure, this information needs to be further validated by field experiments.

Manjari (University College for Women, Koti, Hyderabad) for the discussions.

Kaur, G., Singh, H. P., Batish, D. R., and Kumar, R. K. (2012) Growth, photosynthetic activity and oxidative stress in wheat (Triticum aestivum) after exposure of lead to soil Journal of Environmental biology 33(2): 265-269.

Kausar, S. A., and Shailaja, K. (2018) Heavy metal contamination in the Soil and fodder grass of Musi River Region, Hyderabad International Journal of Research and Analytical Reviews 5(2): 823-829.

Khan, M. M., Islam, E., Irem, S., Akhtar, K., Ashraf, M. Y., Iqbal, J., and Liu, D. (2018) $\mathrm{Pb}$-induced phytotoxicity in para grass 
(Brachiaria mutica) and Castorbean (Ricinus communis L.): antioxidant and ultrastructural studies Chemosphere 200: 257-265.

McCauley, A., Jones, C., and Jacobsen, J. (2009) Plant nutrient functions and deficiency and toxicity symptoms Nutrient management module 9: 1-16.

Milla-Lewis, S. R., Kimball, J. A., Claure, T. E., Tuong, T. D., Arellano, C., and Livingston III, D. P. (2013) Freezing tolerance and the histology of recovering nodes in St. Augustinegrass International Turfgrass Society Research Journal 12 : 523-530.

Nas, F. S., and Ali, M. (2018) The effect of lead on plants in terms of growing and biochemical parameters: a review MOJ Ecology \& Environmental Sciences 3(4): 265-268.

Nascimento, S. S., Silva, E. B., Alleoni, L. R. F., Grazziotti, P. H., Fonseca, F. G., and Nardis, B. O. (2014) Availability and accumulation of lead for forage grasses in contaminated soil Journal of Soil Science and Plant Nutrition 14(4): 783802.

Parth, V., Murthy, N. N., and Saxena, P. R. (2011) Assessment of heavy metal contamination in soil around hazardous waste disposal sites in Hyderabad city (India): natural and anthropogenic implications Journal of Environmental research and management 2(2): 027034.

Ray, M. and Banerjee, S. (1981) Detection of phytotoxicity in irrigation water passing through an industrial belt of West Bengal In Proceeding of VI international conference on women engineers and scientists (pp. 59-65).

Sharma, P., and Dubey, R. S. (2005) Lead toxicity in plants Brazilian journal of plant physiology 17(1): 35-52.

Tow, S. W. T., Eng, Z. X., Wong, S. P., Ge, L., Tan, S. N., and Yong, J. W. H. (2018) Axonopus compressus (Sw.) Beauv.: a potential biomonitor for molybdenum in soil pollution International journal of phytoremediation 20(14): 1363-1368.

Ukoh, S.N.B., Akinola, M.O. and Njoku, K.L. (2019) Comparative study on the growth response and remediation potential of Panicum maximum and Axonopus compressus in lead contaminated soilTechnogenic and Ecological Safety 5(1): 3-12. 